\title{
Commencement of luteal activity in three different selection lines for milk yield and fertility in Norwegian Red cows
}

\author{
R. T. Garmo, ${ }^{* 1}$ E. Ropstad, ${ }^{*} \varnothing$. Havrevoll,† E. Thuen,‡ H. Steinshamn,§ A. Waldmann,\# and O. Reksen* \\ *Norwegian School of Veterinary Science, Department of Production Animal Clinical Sciences, PO Box 8146 Dep., NO-0033 Oslo, Norway \\ †Nortura Rudshøgda, PO Box 70, NO-2360 Rudshøgda, Norway \\ $\ddagger$ Norwegian University of Life Science, Department of Animal Science, NO-1432 Ås, Norway \\ $\S N o r w e g i a n$ Institute for Agricultural and Environmental Research, Organic Food and Farming Division, NO-6630 Tingvoll, Norway \\ \#Estonian University of Life Sciences, 62 Kreutzwaldi Street, 51014 Tartu, Estonia
}

\section{ABSTRACT}

Relationships among commencement of luteal activity (C-LA), milk yield, and energy balance (EB) were investigated in 3 selection lines of Norwegian Red cows at the Norwegian University of Life Sciences from 1994 through 2001. The cows were selected for low genetic merit for milk yield (LMP), high genetic merit for milk yield (HMP), and a combination of high indices for milk yield and fertility (HI). Breeding values for fertility were based on 56-d nonreturn rate. The material included 268 lactations from 147 cows. Milk samples for progesterone analysis were drawn 3 times weekly from 1994 through 1998, and 2 times weekly from 1999 to 2001. Commencement of luteal activity was defined as the first 2 consecutive measurements of progesterone concentration $>3 \mathrm{ng} / \mathrm{mL}$ not earlier than $10 \mathrm{~d}$ after calving. Selection line was significantly related to C-LA, so that the least squares mean days from calving to C-LA were 22.5, 30.4, and $27.2 \mathrm{~d}$ for LMP, HMP, and HI cows, respectively. The HMP cows produced more milk than the LMP cows. The average milk yield in the sixth week of lactation was 24.0, 27.1, and $25.3 \mathrm{~kg}$ for LMP, HMP, and HI cows, respectively. The interval to C-LA decreased for the HMP and HI cows after phenotypic adjustment for EB in the model. Least squares means for the interval to C-LA were 23.2, 29.7, and $25.6 \mathrm{~d}$ for the LMP, HMP, and HI cows, respectively, in a model that included parity, selection lines, and EB as covariates. Cumulated EB during the first 4 wk of lactation, which itself differed between selection lines, did not fully account for differences in interval to C-LA between selection lines. Thus, the results of the present investigation indicate that selection for milk yield negatively affects C-LA over and above the effects caused by concurrent changes in EB. The increase in days to

Received April 24, 2008

Accepted January 5, 2009.

${ }^{1}$ Corresponding author: randi.garmo@veths.no
C-LA caused by selection for high yields can be reduced if selection for milk yield is combined with fertility in the breeding program.

Key words: luteal activity, genetic merit, fertility, dairy cow

\section{INTRODUCTION}

Since the 1970s, milk yield per cow has increased rapidly because of intense genetic selection, improved management, and better nutrition. However, fertility in dairy cows has declined in recent decades. Potential factors such as increased milk production that is associated with negative energy balance (EB), larger herd size, and higher inbreeding percentages have been suggested as reasons for infertility in dairy cows (Lucy, 2001).

In recent years, the effects of genetic merit of milk yield on fertility have been of considerable interest. Unfavorable genetic correlations exist between milk yield and reproductive performance (Veerkamp et al., 2001; Royal et al., 2002; Pryce et al., 2004). Several studies on reproductive efficiency have been performed. Gutierrez et al. (2006) reported that commencement of luteal activity (C-LA) occurred later in cows with high EBV for milk production than in cows with low EBV for milk production. This is in accordance with MacKey et al. (2007) who reported that reproductive performance was negatively associated with both genetic merit for milk yield and actual level of milk production. The level of milk production had the greatest negative effect on reproductive performance, suggesting that poor fertility is caused by an inability to meet the nutritional requirements for an individual cow. Patton et al. (2007) found no associations between milk yield and resumption of ovarian activity, but reported a more negative EB to be associated with later C-LA and noted that DMI was the primary component of EB affecting reproduction. Reksen et al. (2001) found that cows with late resumption of ovarian activity produced more milk than cows with early and middle responses, suggest- 
Table 1. Distribution of number of lactations by parity and selection lines: low milk production (LMP), high milk production (HMP), and high index for milk yield and fertility (HI)

\begin{tabular}{lccc}
\hline & \multicolumn{3}{c}{ Selection line } \\
\cline { 2 - 4 } Parity & LMP & HMP & HI \\
\hline First parity & 26 & 32 & 59 \\
Second parity & 21 & 31 & 50 \\
$>$ Second parity & 26 & 18 & 5 \\
\hline
\end{tabular}

ing that moderately yielding cows may compensate for energy deficits by decreasing milk yield, which on a genetic level could be explained by an increase in C-LA per unit of PTA for milk yield in high-producing cows (Royal et al., 2002). Thus, there are marked indications of unfavorable phenotypic and genotypic associations between milk yield and C-LA. Although the phenotypic correlation between C-LA and EB has been recognized (Reksen et al., 2001; Patton et al., 2007), less is known about the relationship between C-LA and selection for milk yield when phenotypic differences in EB are accounted for.

Fertility traits can be divided into traditional fertility traits and endocrine fertility traits (Royal et al., 2000). Traditional fertility traits such as calving interval, days to first service, 56-d nonreturn rate, and number of inseminations per conception have very low heritabilities (Pryce et al., 1997; Wall et al., 2003; Jamrozik et al., 2005), whereas endocrine fertility traits, which include interval to C-LA, length of first luteal phase, and occurrence of persistent corpus luteum, all have moderate heritability (Darwash et al., 1997; Royal et al., 2002; Petersson et al., 2007). In contrast to the majority of countries, in Norway, female fertility has been included in the total merit index of the Norwegian Red since 1972 (Andersen-Ranberg et al., 2005). The relative emphasis on fertility has been 8 to $15 \%$ throughout this period. Historically, the trait used in selection was the 56-d nonreturn rate of virgin heifers. Since 2002 a combination of 56-d nonreturn rate in heifers and first-lactation cows has been used (Andersen-Ranberg et al., 2005).

The unfavorable correlated response to selection for milk yield on C-LA has been proposed to be caused by a strong association between the length of the anovulatory period postpartum and EB (Butler, 2003). The proportion of the interval between calving and C-LA that is due to differences in EB within and between selection lines can be determined for by including EB in the statistical model. Thus, an estimate of the correlated response between selection for milk yield and C-LA, which is accountable to factors other than EB, may be obtained by adjusting for EB.
In the current study, days to C-LA was compared between 3 selection lines for milk yield and fertility: low milk yield (LMP), high milk yield (HMP), and high index for both milk yield and fertility (HI). The objectives of the study were 1) to quantify the differences in C-LA, milk yield, and EB between the selection lines; and 2) to assess how much of the differences in C-LA between the selections lines could be accounted for by the phenotypic differences in EB.

\section{MATERIALS AND METHODS}

The material included 3 selection lines of Norwegian Red cows (LMP, HMP, and HI), managed in a feeding trial designed to assess the effects of different levels of concentrate on reproduction, milk yield, and EB at the Norwegian University of Life Science from 1994 to 2001. The cows were followed from calving until pregnancy was verified, and the material included 268 lactations from 147 Norwegian Red cows (Table 1).

\section{Selection Lines}

The selection lines for the LMP and HMP cows were established between 1978 and 1989 by the use of lowand high-ranked sires for 305-d milk yield, respectively (Heringstad et al., 2003). Throughout the study period, cows in the LMP selection line were bred to a group of 11 sires that were progeny tested in 1978 and 1979 with EBV of 92.0 (SD \pm 3.7 ) for milk yield and 102.0 $(\mathrm{SD} \pm 10.6)$ for fertility from their first progeny test. To avoid inbreeding, none of the bulls were used for AI in their own progeny lines. The EBV for the maternal grandsires were 92.2 (SD \pm 3.1$)$ for milk yield and 101.7 (SD \pm 7.0) for fertility from their first progeny test. The HMP cows were sired by the 3 to 4 highest ranking proven sires (total 22 sires) for milk production from the most recent group of progeny-tested Norwegian Red sires each year. The EBV for the sires were 111.7 $(\mathrm{SD} \pm 4.1)$ for milk yield and $102.4(\mathrm{SD} \pm 8.3)$ for fertility. The sires were only used for $1 \mathrm{yr}$ to avoid inbreeding. The EBV for the maternal grandsires were $110.8(\mathrm{SD} \pm 4.9)$ for milk yield and 103.5 $(\mathrm{SD} \pm 8.4)$ for fertility. The HI cows were sired by the progenytested, top-ranked Norwegian Red bulls (elite bulls), before commencement of the study and until the end of study in 2001. The EBV for the sires were 109.0 (SD \pm 5.6 ) for milk yield and 102.9 (SD \pm 6.9 ) for fertility. The EBV for the maternal grandsires were 108.1 (SD \pm 5.6 ) for milk yield and 101.3 (SD \pm 6.3 ) for fertility. The cows comprising the selection line for high milk production and fertility reflected the genetic trend for the population of Norwegian Red throughout the study period. Fertility has been included in the total merit 
index as 56-d nonreturn rate since 1972. The relative emphasis on fertility has been between 8 to $15 \%$ during the entire period (Andersen-Ranberg et al., 2005). The following traits (and relative weights) were included in the breeding program in 1998: milk yield (21\%), mastitis resistance $(21 \%)$, udder conformation (11\%), fertility (14\%), growth rate (12\%), conformation (6\%), temperament (4\%), diseases other than mastitis (3\%), stillbirth (4\%), and dystocia (4\%; Geno Breeding and AI Association, 1998).

Estimated breeding values for the cows in the current lactation were obtained from the Norwegian Dairy Herd Record System and were estimated from the following formula: $\mathrm{EBV}=(\mathrm{I}-100) \times 0.8+1 / 2 \mathrm{SBV}+1 / 4$ MSBV $+1 / 8 \mathrm{SMMBV}$, where $\mathrm{I}=$ the milk index for the cow, $\mathrm{SBV}=\mathrm{EBV}$ for the sire excluding milk traits, $\mathrm{MSBV}=\mathrm{EBV}$ for the maternal grandsire excluding milk traits, and SMMBV = EBV for the sire of the maternal grandmother excluding milk traits. The EBV for the cows were $-12.8,3.6$, and 6.2 for the LMP, HMP, and HI cows, respectively.

\section{Management}

The cows were milked twice daily. The breeding season started in early November and continued until February each year. The cows were on pasture from late May to early September. Only healthy untreated cows that calved during the indoor season were included in the study.

\section{Milk Yield and Milk Progesterone}

Milk weights were recorded on 3 consecutive days each week. The average weekly milk yield for the first 10 wk postpartum was calculated for each lactation. Milk progesterone concentrations were measured every Monday, Wednesday, and Friday from 1994 throughout 1998, and every Monday and Friday from 1999 to 2001, by an enzyme immunoassay (Waldmann, 1993), modified by using the second antibody coating technique. The specificity of the antibody has been described previously (Waldmann, 1999). The interassay coefficients of variation for milk progesterone concentrations of 1.48 and $19.66 \mathrm{ng} / \mathrm{mL}$ were 9.21 and $5.32 \%$, respectively. The intraassay coefficient of variation was $<10 \%$. Milk progesterone concentrations were used to determine the interval from calving to C-LA. The interval from calving to C-LA was defined as the first 2 consecutive measurements of progesterone concentration $>3 \mathrm{ng} / \mathrm{mL}$ more than $10 \mathrm{~d}$ after calving.

\section{Concentrate Allocation}

The cows were assigned group wise to different concentrate rations such that the groups were similar in terms of BW, age, body condition, and selection line for milk production. The first-parity cows received either 5 or $9 \mathrm{~kg} / \mathrm{d}$ of concentrate during peak lactation (until 90 DIM), whereas the second-parity cows received either 6.5 or $11 \mathrm{~kg} / \mathrm{d}$ during peak lactation from 1994 to 1998. From 1999 to 2001, the cows were divided into 4 groups balanced for calving date and parity and which received $4,8,12$, or $16 \mathrm{~kg} / \mathrm{d}$ of concentrate during peak lactation.

\section{Energy Requirements}

The DM of the feed was determined weekly, and ash, CP, crude fat, crude fiber, and NDF content were calculated monthly according to standard procedures (AOAC, 1995). Protein degradability of roughage was measured in a composite feed sample collected over a 3-mo period. Protein degradability of concentrate was analyzed in a composite sample collected throughout the entire indoor feeding period. Digestibility of DM was assessed in trials conducted for each of the 2 main feeds (grass silage and concentrate; Madsen et al., 1995). Dry matter intake was calculated as DM offered minus DM refused, on 3 consecutive days in a week.

Energy content in dry matter and energy requirements were calculated according to the Norwegian feeding value per unit of milk (FUM) system (Ekern, 1991), in which $1 \mathrm{FUM}$ is equal to $6.9 \mathrm{MJ}$ of $\mathrm{NE}_{\mathrm{L}}$. Energy intake was calculated as $\mathrm{FUM}_{\text {intake }}=\mathrm{DMI} \times$ food FUM concentration. Energy requirements are dependent upon maintenance, growth, and milk production according to the following formulae (Van Der Honing and Alderman, 1988):

$$
\begin{aligned}
& \text { Energy requirements }=\mathrm{FUM}_{\text {maintenance }} \\
& +\mathrm{FUM}_{\text {milk }}+\mathrm{FUM}_{\text {growth }} \\
& \mathrm{FUM}_{\text {maintenance }}=0.0424 \times \mathrm{BW}^{0.75} \text {, } \\
& \text { where BW = body weight; } \\
& \mathrm{FUM}_{\text {milk }}=0.44 \times \mathrm{ECM}+0.0007293 \times \mathrm{ECM}^{2}, \\
& \text { where } \mathrm{ECM}=\text { daily ECM yield }[\mathrm{kg}]=\mathrm{kg} \text { milk } \\
& \times[0.25+(0.122 \times \text { fat } \%)+0.077 \times \text { protein } \%)] \text {; and } \\
& \left.\mathrm{FUM}_{\text {growth }} \text { (first-parity cows }\right)=0.45 \text {. }
\end{aligned}
$$


Table 2. Cumulative average energy balance for the first $4 \mathrm{wk}$ (CAEB wk 1-4), and weekly point estimates of average energy balance (EB) and milk yield (MY) from wk 2 to 10 postpartum between cows selected for low milk yield (LMP), high milk yield (HMP), and high genetic merit for milk yield and fertility (HI) as assessed by mixed linear models ${ }^{1}$

\begin{tabular}{|c|c|c|c|c|c|c|c|}
\hline \multirow[b]{2}{*}{ Item } & \multirow[b]{2}{*}{$\mathrm{n}$} & \multicolumn{2}{|c|}{ LMP } & \multicolumn{2}{|c|}{ HMP } & \multicolumn{2}{|c|}{$\mathrm{HI}$} \\
\hline & & LSM & $\mathrm{SE}$ & LSM & $\mathrm{SE}$ & LSM & $\mathrm{SE}$ \\
\hline CAEB wk 1-4 & 268 & $-9.77^{\mathrm{a}}$ & 2.04 & $-13.97^{\mathrm{ab}}$ & 1.93 & $-15.71^{\mathrm{b}}$ & 1.61 \\
\hline EB wk 4 & 263 & $-4.89^{\mathrm{a}}$ & 2.25 & $-8.47^{\mathrm{a}}$ & 2.11 & $-11.49^{\mathrm{a}}$ & 1.80 \\
\hline EB wk 6 & 258 & $-4.64^{\mathrm{a}}$ & 2.21 & $-6.02^{\mathrm{a}}$ & 2.11 & $-8.25^{\mathrm{a}}$ & 1.79 \\
\hline $\mathrm{EB}$ wk 8 & 253 & $-3.02^{\mathrm{a}}$ & 2.28 & $-6.33^{\mathrm{a}}$ & 2.10 & $-6.25^{\mathrm{a}}$ & 1.81 \\
\hline MY wk 2 & 239 & $22.27^{\mathrm{a}}$ & 0.72 & $24.48^{\mathrm{a}}$ & 0.69 & $23.01^{\mathrm{a}}$ & 0.60 \\
\hline MY wk 4 & 263 & $23.74^{\mathrm{a}}$ & 0.66 & $27.03^{\mathrm{b}}$ & 0.63 & $24.96^{\mathrm{a}}$ & 0.54 \\
\hline MY wk 6 & 258 & $23.96^{\mathrm{a}}$ & 0.68 & $27.14^{\mathrm{b}}$ & 0.65 & $25.31^{\mathrm{ab}}$ & 0.56 \\
\hline MY wk 8 & 253 & $23.85^{\mathrm{a}}$ & 0.68 & $26.68^{\mathrm{b}}$ & 0.62 & $24.90^{\mathrm{ab}}$ & 0.53 \\
\hline MY wk 10 & 252 & $23.29^{\mathrm{a}}$ & 0.66 & $26.07^{\mathrm{b}}$ & 0.60 & $25.09^{\mathrm{ab}}$ & 0.52 \\
\hline
\end{tabular}

${ }^{\mathrm{a}, \mathrm{b}}$ Different superscripts indicate significant differences between selection lines by Bonferroni adjustment for multiple comparisons, $P<0.05$.

${ }^{1}$ Least squares means.

Energy balance in FUM was estimated as the difference between energy intake and energy requirements for maintenance, growth in first-lactation cows, and milk production.

\section{Statistical Analysis}

All calculations were performed using SAS, version 9.1 (SAS Institute Inc., Cary, NC). Mixed linear models were performed (Littell et al., 1996) to assess differences in EB and milk yield between selection lines (LMP, HMP, HI) for each of the 12 postpartum weeks. The models adjusted for multiple lactations within the same cow by the use of a compound symmetry correlation structure.

Mixed linear models were also performed to assess relationships between the natural logarithm of days to C-LA (lnC-LA) and explanatory variables. The outcome variable, days to C-LA, was transformed by natural logarithm to obtain approximate normality of residuals. The first model included selection line and parity $(1,2$, and $>2)$ as fixed effects. A second model included parity and the cumulative average EB for the first 4 wk postpartum (CAEB 1-4) as fixed effects. Cumulative average EB for the first 4 wk postpartum was used to avoid random fluctuations that may occur if point estimates were used. A third model included parity, selection line, and CAEB 1-4 as fixed effects. The interaction between selection line and CAEB 1-4 was tested in this model, but omitted as it was not significant. Covariance between multiple lactations within the same cow was included as a compound symmetry correlation structure. Level of concentrate allocation was included in the models as a random effect. A single index notation of these models can be expressed as: $\operatorname{lnC}-\mathrm{LA}_{\mathrm{ijk}}=\beta_{0}+\beta_{1} \ldots \beta_{\mathrm{n}}+\mathrm{Z}_{\gamma \mathrm{ij}}+\mathrm{U}_{\gamma \mathrm{k}}+e$, where $\mathrm{i}$ corresponds to ith lactation number; $\mathrm{j}$ to observation at jth individual; $\beta_{0}=$ intercept; $\beta_{1} \ldots \beta_{\mathrm{n}}=$ fixed effects; $Z_{\gamma i j}$ represents the repeated effects for the ith lactation period within jth individual; $\mathrm{U}_{\gamma \mathrm{k}}=$ random effect of concentrate allocation; and $e=$ residual error term. Multiple comparison adjustment for the pairwise difference in least squares means was performed using the Bonferroni option in SAS. Statistical significance was considered at $P$-values $<0.05$.

\section{RESULTS}

Least squares (LS) means of the cumulative average weekly EB, CAEB1-4, and milk yield during the first $10 \mathrm{wk}$ of lactation are presented by selection line in Table 2. There was no significant difference in weekly EB between the selection lines except for the second week, where the HI cows had lower EB than the LMP cows (Table 2). Milk yield differed between selection lines in that HMP cows yielded more than LMP cows, whereas no significant differences in milk yield were observed between the HI and LMP cows or the HI and HMP cows (Table 2).

In the model with parity and selection line as the fixed effects, lnC-LA was only associated with selection line $(P=0.02)$ as assessed by the $F$-test. The LS means for $\operatorname{lnC}$-LA were $3.106 \pm 0.078,3.407 \pm 0.073$, and 3.287 \pm 0.066 for the LMP, HMP, and HI cows, representing an interval from calving to C-LA of 22.3, 30.2, and 26.8 d for LMP, HMP, and HI cows, respectively.

In the model with parity and EB included as fixed effects, lnC-LA was associated with both parity $(P<$ 
Table 3. Associations between number of days to commencement of luteal activity (C-LA, natural logarithmic transformed) as assessed by a mixed linear model corrected for level of concentrate allocation as random effects variable and fixed effects variables; parity, selection lines for high (HMP), low (LMP) milk yield, and high genetic merit for milk yield and fertility (HI)

\begin{tabular}{lccc}
\hline Item & Least squares means & SE & Days to C-LA \\
\hline Parity & & & \\
First parity & $3.398^{\mathrm{a}}$ & 0.052 & 29.9 \\
Second parity & $3.199^{\mathrm{b}}$ & 0.054 & 24.5 \\
> Second parity & $3.178^{\mathrm{ab}}$ & 0.081 & 24.0 \\
Selection line & & & \\
LMP & $3.144^{\mathrm{a}}$ & 0.074 & 23.2 \\
HMP & $3.390^{\mathrm{b}}$ & 0.068 & 29.7 \\
HI & $3.241^{\mathrm{ab}}$ & 0.063 & 25.6 \\
\hline
\end{tabular}

${ }^{\mathrm{a}, \mathrm{b}}$ Different superscripts indicate significant differences between parities or selection lines by Bonferroni adjustment for multiple comparisons, $P<0.05$.

$0.01)$ and $\mathrm{EB}(P<0.01)$. The LS means for $\operatorname{lnC}-\mathrm{LA}$ were $3.402 \pm 0.053,3.205 \pm 0.053$, and $3.173 \pm 0.081$ for first parity, second parity, and >second parity, representing an interval from calving to C-LA of 30.0, 24.7, and $23.9 \mathrm{~d}$ for first parity, second parity, and > second parity, respectively. The estimate for EB in this model was $-0.0098 \pm 0.0019$.

Associations between lnC-LA and the fixed effects selection line, parity, and EB in the third model are presented in Table 3 . In this model, lnC-LA was associated with parity $(P<0.01)$, selection line $(P=0.04)$, and EB $(P<0.01)$. The estimate for EB in this model was $-0.0094 \pm 0.0020$. The LS means for days from calving to C-LA were 23.2, 29.7, and $25.6 \mathrm{~d}$ for the LMP, HMP, and HI cows, respectively, and 29.9, 24.5, and $24.0 \mathrm{~d}$ for first parity, second parity, and > second parity, respectively, when EB was included in the model in addition to parity and selection line.

The difference in C-LA between the HMP and LMP cows was $7.9 \mathrm{~d}$ when parity and selection line were included in the first model, but the difference between the HMP and LMP cows decreased to $6.5 \mathrm{~d}$ when phenotypic differences in EB were accounted for in the model.

\section{DISCUSSION}

It has been emphasized that fertility should be included in breeding goals to reverse the trend of declining fertility in dairy cows, because unfavorable genetic correlations exist between milk yield and reproductive performance (Veerkamp et al., 2001; Royal et al., 2002; Pryce et al., 2004). Currently, female fertility is included in selection indices in several other countries (VanRaden, 2004; Miglior et al., 2005). In the present study, cows selected for high milk yield had a longer in- terval from calving to C-LA than cows selected for low milk yield, whereas the interval to C-LA was intermediary in cows selected for both yield and fertility. Thus, less selection pressure for milk yield and more weight on fertility in a breeding program does not necessarily reduce milk yield substantially, despite the fact that an increase in C-LA per unit of PTA for milk yield is expected in high-producing cows (Royal et al., 2002).

There was a strong association between C-LA and EB that was of similar magnitude in the models with and without selection line included as a fixed effect. The interval to C-LA was reduced for the HMP and HI cows after adjustment for phenotypic differences in EB between the selection lines. This is in agreement with the unfavorable genetic correlations between milk yield and fertility reported in previous studies on both a phenotypic level (Gutierrez et al., 2006; Patton et al., 2007) and a genetic level (Veerkamp et al., 2001; Royal et al., 2002; Pryce et al., 2004), because the degree of negative EB stems from the milk yield in early lactation and hence influences the interval to C-LA.

To our knowledge, the present study is the first to evaluate and compare C-LA in cows selected for low milk yield, high milk yield, or the combination of high indices for milk yield and fertility. By managing the cows in a single herd, phenotypic variation resulting from different management and feeding practices was minimized. Additionally, valuable information about the reproductive performance and milk production of Norwegian Red cows from the 3 different selection lines was obtained. The LMP cows may be used as a baseline, representing the phenotype between 1978 and 1979; HMP cows may be viewed as a phenotype representing reproductive performance and milk yield in Norwegian Red cows, in which selection has been more focused toward milk yield and less toward fertility and other functional traits; and the HI group can be considered as representative of current breeding objectives.

In previous experiments (Westwood et al., 2000; Gutierrez et al., 2006) and population studies (Royal et al., 2000) of differences in reproductive performance between cows with high and low genetic merit for milk yield, contemporary sires with breeding indices for high and low milk yield have been used. In the present study, sires of cows selected for low milk yield were dated back to progeny test results from 1978 and 1979, whereas the sires used for AI in cows selected for high milk yield were the 3 to 7 highest ranking proven sires for milk yield in the most recent group of progeny-tested Norwegian Red sires during each year of the study. Thus, cows expressing selection responses from 16 to $23 \mathrm{yr}$ of breeding were housed and fed beside cows in which no selection responses could be expected since 1979, even though changes in gene frequency to some 
extent could occur by chance alone in small populations (Simm, 2000).

After adjustment for phenotypic differences in EB, there was still a difference in days to C-LA of 6.5 and $2.4 \mathrm{~d}$ for the HMP and HI cows, respectively, compared with the LMP cows. Thus, the reduction in reproductive efficiency following selection for high milk yield must be attributable to factors other than negative EB because of high milk production. It has been shown that cows with a high genetic merit for milk yield mobilize more body tissue in early lactation than cows with average merit for milk yield on a genetic level (Pryce et al., 2001) and on a phenotypic level (Westwood et al., 2000; Pryce et al., 2001). The heritability for BCS is high (0.38; Veerkamp et al., 2001), and there is a strong and negative genetic correlation between BCS and milk yield (Veerkamp et al., 2001; Wall et al., 2003), which may lead to greater negative EB and reduction in fertility in cows selected for high milk yield. Westwood et al. (2000) reported that mean BCS and pattern of BCS changes differed between high- and low-yielding cows because high-genetic-merit cows mobilized more body tissue in early lactation than cows with a lower production potential. Hayhurst et al. (2007) reported that the amounts of free fatty acids and glucose in male calves were moderately heritable and could be used to enhance selection for improved female fertility. Calves that mobilized large amounts of free fatty acids tended to have female offspring with reduced fertility. Thus, selection for milk yield could lead to more body tissue mobilized and hence a higher level of free fatty acids leading to reduced fertility such that the interval from calving to C-LA is increasing.

Previous phenotypic studies reported that cows with higher plasma concentrations of IGF-1 had an increased likelihood of a shorter interval to C-LA, whereas plasma concentrations of insulin, glucose, NEFA, and BHBA were not associated with C-LA (Patton et al., 2007). Westwood et al. (2000) reported higher concentrations of growth hormone in cows with high genetic merit for milk yield, whereas Gutierrez et al. (2006) found higher concentrations of growth hormone and BHBA, and lower concentrations of insulin, glucose, and IGF-1 in cows with high genetic merit for milk yield. Although assessments of hormone and metabolic profiles were not objectives of the current study, it should be emphasized that further research is necessary to investigate which factors other than negative EB affect the phenotypic difference in days to C-LA between cows selected for low or high milk production.

Selection for shorter intervals to C-LA, which has moderate heritability, may be a feasible approach to improving fertility (Darwash et al., 1997). However, despite obtaining a shorter interval to C-LA by inclusion of fertility as nonreturn rate in the breeding program, inclusion of C-LA only as a fertility trait in a breeding program should be considered with caution because of the increased risk of persistent corpus luteum rather than continuous cyclical luteal activity after early C-LA (Royal et al., 2002; Petersson et al., 2007). Thus, both traditional and endocrinological fertility traits should be included in a breeding program to improve cow fertility in a sustainable manner.

First-parity cows had longer intervals to C-LA compared with second-parity cows. This agrees with Petersson et al. (2006), but contrasts with the reports from Darwash et al. (1997) who reported that the interval increased with parity. Previous studies have reported the interval to C-LA to be 33.8 d (Petersson et al., 2006), 31.0 d (Patton et al., 2007), 29.5 d (Veerkamp et al., 2000), and $25.6 \mathrm{~d}$ (Darwash et al., 1997). These figures correspond with those obtained for the HMP cows of the present study.

\section{CONCLUSIONS}

Cows selected exclusively for high milk yield experienced a longer interval from calving to C-LA than cows with no selection response for milk yield. The interval to C-LA in cows selected for both milk production and fertility was intermediate between the high and low milk production lines. Energy balance was significantly related to C-LA, and correction for EB accounted for part of the difference in time to C-LA between the selection lines. The increase in the interval from calving to C-LA by selection for high milk yields can be reduced by inclusion of fertility traits in the breeding program.

\section{ACKNOWLEDGMENTS}

The authors gratefully acknowledge the staff at the Animal Research Center (Ås, Norway) for taking good care of the animals and for skillful registration of data. We also acknowledge the staff at the Norwegian University of Life Sciences, Department of Animal and Aquacultural Sciences, and the Norwegian School of Veterinary Science, Department of Production Animal Clinical Sciences, for technical assistance. These experiments were financially supported by Research Council (Oslo) of Norway, TINE Norwegian Dairies (Ås), and Geno Breeding and AI Association (Hamar, Norway).

\section{REFERENCES}

Andersen-Ranberg, I. M., G. Klemetsdal, B. Heringstad, and T. Steine. 2005. Heritabilities, genetic correlations, and genetic change for female fertility and protein yield in Norwegian dairy cattle. J. Dairy Sci. 88:348-355.

AOAC. 1995. Official Methods of Analysis. Vol. IV. 16th ed. AOAC, Gaithersburg, MD. 
Butler, W. R. 2003. Energy balance relationships with follicular development, ovulation and fertility in postpartum dairy cows. Livest. Prod. Sci. 83:211-218.

Darwash, A. O., G. E. Lamming, and J. A. Woolliams. 1997. Estimation of genetic variation in the interval from calving to postpartum ovulation of dairy cows. J. Dairy Sci. 80:1227-1234.

Ekern, A. 1991. A new system of energy evaluation of food for ruminants. Norsk Landbruksforskning. 5:273-277.

Geno Breeding and AI Association. 1998. Annual report (In Norwegian). Geno Breeding and AI Association, Hamar, Norway.

Gutierrez, C. G., J. G. Gong, T. A. Bramley, and R. Webb. 2006 Selection on predicted breeding value for milk production delays ovulation independently of changes in follicular development, milk production and body weight. Anim. Reprod. Sci. 95:193-205.

Hayhurst, C., M. K. Sørensen, M. D. Royal, and P. Løvendahl. 2007. Metabolic regulation in Danish bull calves and the relationship to the fertility of their female offspring. J. Dairy Sci. 90:3909-3916.

Heringstad, B., G. Klemetsdal, and T. Steine. 2003. Selection responses for clinical mastitis and protein yield in two Norwegian dairy cattle selection experiments. J. Dairy Sci. 86:2990-2999.

Jamrozik, J., J. Fatehi, G. J. Kistemaker, and L. R. Schaeffer. 2005. Estimates of genetic parameters for Canadian Holstein female reproduction traits. J. Dairy Sci. 88:2199-2208.

Littell, R. C., G. A. Miliken, W. W. Stroup, and R. D. Wolfinger. 1996. SAS System for Mixed Models. SAS Institute Inc., Cary, NC.

Lucy, M. C. 2001. Reproductive loss in high-producing dairy cattle: Where will it end? J. Dairy Sci. 84:1277-1293.

MacKey, D. R., A. W. Gordon, M. A. McCoy, M. Verner, and C. S. Mayne. 2007. Associations between genetic merit for milk production and animal parameters and the fertility performance of dairy cows. Animal 1:29-43.

Madsen, J., T. Hvelpelund, M. R. Weisbjerg, J. Bertilson, I. Olsson, R. Spörndly, O. M. Harstad, H. Volden, M. Tuori, T. Varvikko, P. Huhtanen, and B. L. Olafsson. 1995. The AAT/PBV protein evaluation system for ruminants. A revision. Norw. J. Agric. Sci. (Suppl. 19).

Miglior, F., B. L. Muir, B. J. Muir, and J. Van Doormal. 2005. Selection indices in Holstein cattle of various countries. J. Dairy Sci. 88:1255-1263.

Patton, J., D. A. Kenny, S. McNamara, J. F. Mee, F. P. O'Mara, M. G. Diskin, and J. J. Murphy. 2007. Relationships among milk production, energy balance, plasma analytes, and reproduction in Holstein-Friesian cows. J. Dairy Sci. 90:649-658.

Petersson, K. J., B. Berglund, E. Strandberg, H. Gustafsson, A. P. F. Flint, J. A. Woolliams, and M. D. Royal. 2007. Genetic analysis of postpartum measures of luteal activity in dairy cows. J. Dairy Sci. 90:427-434.

Petersson, K. J., E. Strandberg, H. Gustafsson, and B. Berglund. 2006. Environmental effects on progesterone profile measures of dairy cow fertility. Anim. Reprod. Sci. 91:201-214.
Pryce, J. E., M. P. Coffey, and G. Simm. 2001. The relationship between body condition score and reproductive performance. J. Dairy Sci. 84:1508-1515.

Pryce, J. E., M. D. Royal, P. C. Garnsworthy, and I. L. Mao. 2004. Fertility in the high-producing dairy cow. Livest. Prod. Sci. $86: 125-135$.

Pryce, J. E., R. F. Veerkamp, R. Thompson, W. G. Hill, and G. Simm. 1997. Genetic aspects of common health disorders and measures of fertility in Holstein Friesian dairy cattle. Anim. Sci. 65:353-360.

Reksen, O., Y. T. Gröhn, O. S. Havrevoll, T. Bolstad, A. Waldmann, and E. Ropstad. 2001. Influence of concentrate allocation and energy balance on postpartum ovarian activity in Norwegian cattle. J. Dairy Sci. 84:1060-1068.

Royal, M. D., A. O. Darwash, A. P. F. Flint, R. Webb, J. A. Woolliams, and G. E. Lamming. 2000. Declining fertility in dairy cattle: changes in traditional and endocrine parameters of fertility. Anim. Sci. 70:487-501.

Royal, M. D., A. P. F. Flint, and J. A. Woolliams. 2002. Genetic and phenotypic relationships among endocrine and traditional fertility traits and production traits in Holstein-Friesian dairy cows. J. Dairy Sci. 85:958-967.

Simm, G. 2000. Genetic Improvement of Cattle and Sheep. 2nd ed. Farming Press, Tonbridge, UK.

Van Der Honing, Y., and G. Alderman. 1988. Feed evaluation systems and requirements. 2. Ruminants. Livest. Prod. Sci. 19:217-278.

VanRaden, P. M. 2004. Selection on net merit to improve lifetime profit. J. Dairy Sci. 87:3125-3131.

Veerkamp, R. F., E. P. C. Koenen, and G. De Jong. 2001. Genetic correlations among body condition score, yield, and fertility in first-parity cows estimated by random regression models. J. Dairy Sci. 84:2327-2335.

Veerkamp, R. F., J. K. Oldenbroek, H. J. Van Der Gaast, and J. H. J. Werf. 2000. Genetic correlation between days until start of luteal activity and milk yield, energy balance, and live weights. J. Dairy Sci. 83:577-583.

Waldmann, A. 1993. Enzyme immunoassay (EIA) for milk progesterone using a monoclonal antibody. Anim. Reprod. Sci. 34:19-30.

Waldmann, A. 1999. Monoclonal antibodies to progesterone: characterization and selection for enzyme immunoassay in bovine milk. Hybridoma 18:289-296.

Wall, E., S. Brotherstone, J. A. Woolliams, G. Banos, and M. P. Coffey. 2003. Genetic evaluation of fertility using direct and correlated traits. J. Dairy Sci. 86:4093-4102.

Westwood, C. T., I. J. Lean, J. K. Garvin, and P. C. Wynn. 2000. Effects of genetic merit and varying dietary protein degradability on lactating dairy cows. J. Dairy Sci. 83:2926-2940. 